BJHS: Themes 2: 35-56, 2017. C British Society for the History of Science 2017. This is an Open Access article, distributed under the terms of the Creative Commons Attribution licence (http:// creativecommons.org/licenses/by/4.0/), which permits unrestricted re-use, distribution, and reproduction in any medium, provided the original work is properly cited.

doi: $10.1017 / b j t .2017 .8$

\title{
Animal agency in the age of the Modern Synthesis: W.H. Thorpe's example
}

\author{
GREGORY RADICK*
}

\begin{abstract}
The mechanical and reductive ideals of much of modern science leave it ill-equipped to recognize, let alone account for, the agency of animals. So says a tradition of criticism well represented in the writings of the British behavioural biologist W.H. Thorpe FRS (1902-1986). This paper recovers the range of overlapping debates and developments, philosophical and religious as well as scientific, which led Thorpe to champion animal agency in the period and place much better known now as headquarters for the neo-Darwinian Modern Synthesis. A retracing of Thorpe's path through such forgotten domains as applied-science Lamarckism and the philosophical psychology of Leonard Hobhouse complicates a now-standard picture (which Thorpe himself promoted) of the Modern Synthesis as inimical to animal agency. Largely thanks to Thorpe's work, as publicized by Julian Huxley, the Modern Synthesis revitalized the fortunes of what became one of the mainstays of agential science, the Baldwin effect.
\end{abstract}

I

What are 'animal agents'? As a general rule, showing is better than telling. For me, nothing better conveys the meaning of the phrase - and the provocative intent of those who use it - than a passage in a 1965 book by the Cambridge entomologistturned-ethologist William H. Thorpe. Neither the book nor the man is especially well remembered. When he wrote it, Thorpe was in his early sixties, and already some way into that phase of a scientific career now derided as the 'philosopause'. Science, Man and Morals put into permanent form lectures he had given in Oxford in 1963, in an annual series devoted to exploring the relationship between science and Christianity. In the first chapter, 'The nature of life and the idea of Creation', he unexpectedly upends the familiar neo-Darwinian tale of the peppered moth in the industrially darkened forests of Britain. Far from illustrating the power of natural selection to adapt organisms to changing environments, the tale in Thorpe's hands showcases the

\footnotetext{
* School of Philosophy, Religion and History of Science, University of Leeds, Leeds LS2 9JT, UK. Email: G.M.Radick@leeds.ac.uk.

I am deeply grateful to Mandy Rees for inviting this contribution, for gently but insistently prodding it into being, and for arranging an anonymous review from which I learned a great deal. It is also a pleasure to record my thanks to Jon Hodge, Chip Burkhardt and Emily Herring for much-appreciated discussion and encouragement along the way.
} 
power of the animal to select its environment and thus to shape the evolutionary future of its species:

[T] he pure Lamarckian conception has never been vindicated. But there is a form of it - or rather what we might call a neo-Lamarckian theory - which is highly cogent. Firstly, there is a continuous living interchange between the organism and its environment; and before an organism's environment can exert natural selection on it, the organism must select the environment to live in. That is, there is a feedback or cybernetic system in which there is nothing that is simply cause and simply effect. It is useless for melanistic moths in industrial areas to become darker unless they choose the dark patches to sit on, which in fact they do. Having made this choice, natural selection [sic - the slip is the more unfortunate given the thrust of the passage] can operate still further. In other words, with each new organ or change of structure, a corresponding change of behaviour is likely to be necessary if the new development is to be a going concern. ${ }^{1}$

The phrase 'animal agents' does not come up here. But it captures tolerably well Thorpe's stress on active choosing by animals as something to be taken seriously. Elsewhere his language was explicitly agential, as in a 1950 lecture on evolution and Christianity which I shall be dealing with at length below. It was his first sustained public statement as a theologically minded scientist, and one of its central messages was the need to reconceptualize the animal under evolution by natural selection as 'a non-deterministic agent acting through the whole ecological complex of life and its environment' ${ }^{2}$

Among the many questions that historians of science might ask about animal agency is the question of what prompts individuals, groups, sciences, eras to take it seriously (or not). In seeking to understand how Thorpe came to ask about animal agency as and when he did, we thus have the opportunity to learn new lessons not only about a particular scientific world - that of the early- to mid-twentieth-century animal behaviour sciences, as encountered by an especially thoughtful participant observer in Britain - but also about the historical trajectory of animal agency as a scientific problem. We will see that Thorpe's work as champion of animal agency can be situated within what became two of the great dissenting traditions in the animal behavioural sciences. One centres on Lamarckian or, as Thorpe came to call it, neo-Lamarckian evolution. The other centres on a kind of animal learning called insight learning. The common theme is that, where animals are concerned, all is not purposeless mechanism. Placing Thorpe in relation to these dissenting traditions, and seeing them as dissenting traditions - as, that is, clusters of ideas and practices that stabilize as protest sciences (here, protest against mechanism) - is one cluster of aims in what follows. Another is to uncover otherwise hidden bonds between Thorpe the research scientist and Thorpe the public theologian. Ronald Fisher, one of the architects of the neo-Darwinian Modern Synthesis and a senior colleague of Thorpe's at Cambridge, will turn out to offer some instructive contrasts.

I will return at the end to consider how a more vivid sense of Thorpe's attentiveness to animal agency might help us reassess a familiar picture of the Modern Synthesis as not

1 W.H. Thorpe, Science, Man and Morals, London: Scientific Book Club, 1965, pp. 15-16.

2 W.H. Thorpe, Evolution and Christian Belief, London: British Social Biology Council, 1951, p. 11. Also published as an article in Biology and Human Affairs (1951) 17, pp. 6-19, 16. 
just inattentive to animal agency but annihilating of it. But I begin at the beginning, which for Thorpe was the 1920s.

\section{II}

In late June 1927, in the improbable setting of the sleepy East Sussex beachside town of St Leonards-on-Sea, the twenty-five-year-old Thorpe found himself giving his first public presentation on his research alongside the grandest of the grand old men in that era's debate on animal behaviour and Darwinian evolution. The occasion was the meeting of the zoological section of the South-Eastern Union of Scientific Societies, gathering for its three-day annual congress. Thorpe set down his recollection of the event half a century later, in his book The Origins and Rise of Ethology (1979):

I was both uplifted and somewhat apprehensive to find that the other two speakers sharing the platform were Lloyd Morgan, who gave a critical evaluation of Eliot Howard's work on territory in bird life, and Professor E.W. M[a]cBride, from the Imperial College of Science in London, a great embryologist and zoologist, who was an indefatigable proponent of Lamarckism. Both speakers were orotund and impressive. M[a]cBride was a pugnacious Ulsterman who took sides on any subject with virulent intensity. One phrase has stuck in my mind, 'I have yet to see the Mendelian mutation which is not pathological.'

Between Morgan and MacBride is not, as it happens, a bad way of imaging what Thorpe came to stand for in the decades that followed. Brief introductions to the work of the older men will prepare the ground for what follows.

Thorpe, looking back, called Morgan's scientific contribution 'so outstanding as to warrant our considering him as one of the founding fathers of both comparative psychology and ethology'. His foundational achievement par excellence, Thorpe explained, was a rule of inference introduced by Morgan in the early 1890s and known ever after as 'Morgan's canon'. Commanding human observers of animals to prefer whatever interpretation of animal actions presumes the least of the powers of animal minds, the canon was widely adopted within comparative psychology from around 1900 onward, as was a phrase little used before Morgan made it a book title in that year: 'animal behaviour'. Morgan never approved of the behaviourist, mind-negating extremes to which some American admirers took the experimental study of animal learning. But he remained convinced of the need to exercise great care in the difficult business of reaching justified claims about animal minds. ${ }^{4}$ At the 1927 meeting, under the title 'Territory in bird life', the seventy-plus-year-old set out his case once again, with some new variations on familiar themes. Bird territoriality was the signature topic of Henry Eliot Howard, a Worcester-based field ornithologist who, as something of a protégé of Morgan's, had come as close as anyone had ever managed to putting Morgan's

3 W.H. Thorpe, The Origins and Rise of Ethology: The Science of the Natural Behaviour of Animals, London: Heinemann Educational, 1979, pp. 29-30. On the 1927 congress see 'South-Eastern Union of Scientific Studies: Annual Congress', Nature (1927) 119, pp. 874-875.

4 Thorpe, op. cit. (3), pp. 26-29, 26; Gregory Radick, 'Morgan, Conwy Lloyd (1852-1936)', in Bernard Lightman (ed.), Dictionary of Nineteenth-Century British Scientists, vol. 3, Bristol: Thoemmes Continuum, 2004, pp. 1425-1426. 
canon into practice in a way that the master found satisfactory. Even so, Howard's latest work provided Morgan with a chance to indulge his own signature topic of distinctionmaking in the service of better interpretations. When we observe a male bird securing or straying from his territory, we need, according to Morgan, to report what happened in not one but three versions: a 'plain-tale', just-the-observed-facts version; a 'body-story' version, telling of how environmental stimuli combined with physiological states and processes to produce movements of particular kinds; and a 'mind-story' version, rerunning it again but in terms of perceptions, emotions, memory and other elements of the bird's inner life. The difficulties encountered in getting the body and mind stories right, and then integrating them, will of course be daunting, Morgan warned. But he nevertheless saw in their challenges a welcome spur to further inquiry and debate. ${ }^{5}$

Morgan's talk at St Leonard's-on-Sea drew on ideas expounded at greater length in his most recent book, Life, Mind and Spirit (1926). It is tempting to see in the book, along with its earlier companion volume Emergent Evolution, published in 1923, a manifesto and even a map for the sort of gently Christian, extremism-avoiding, behaviour-and-evolution-focused journeying that would absorb Thorpe so thoroughly for so much of his later career. The two books memorialized Morgan's Gifford Lectures in natural theology at St Andrews in 1922-1923. As Morgan noted in his preface to Emergent Evolution, they represented his most comprehensive statement of themes that had occupied him ever since his days as a student in the laboratory of T.H. Huxley. Alone among Darwin's immediate circle, Huxley had seen no contradiction in believing both that species evolve naturally and that nature makes occasional leaps. Morgan proposed 'emergent evolution' as a name for this position, stressing its credentials as a via media that avoided the pitfalls of dogmatic mechanism on the one side and of supernaturalist vitalism on the other. It acknowledged that at certain points in the progress of evolution, and by presumptively wholly natural means, genuine novelty - something more than the mere summation of what was already in play - came about. In Life, Mind and Spirit, Morgan urged that his canon now be understood as an extension to the interpretation of animal behaviour of emergent evolution, as it enjoined the observer not to attribute to animal minds faculties belonging to a later stage of evolution. As to why nature should proceed in this progressive, stage-by-stage way, the ultimate answer, Morgan reckoned, was that such was the workings of, in his term, 'Divine Purpose'. Life and mind were but earlier and later, physical and mental, manifestations of the ultimate substance: spirit. ${ }^{6}$

5 C. Lloyd Morgan, 'Territory in bird life', Transactions of the South-Eastern Union of Scientific Societies (1927), pp. 22-26. Of Howard, Morgan wrote, 'Few equal him in accuracy of observation, in plain-tale description, and in cautious interpretation with due regard to life-story and to mind-story.' Morgan, Life, Mind and Spirit, London: Williams and Norgate, 1926, p. 154. On Morgan and Howard see Richard W. Burkhardt Jr, Patterns of Behavior: Konrad Lorenz, Niko Tinbergen, and the Founding of Ethology, Chicago: The University of Chicago Press, 2005, pp. 94-97.

6 C. Lloyd Morgan, Emergent Evolution, London: Williams and Norgate, 1923; Morgan, Life, Mind and Spirit, op. cit. (5), esp. pp. $37 \mathrm{ff}$. for the animal behaviour '-story' distinctions, 61 for the emergentist gloss on the canon, and $\mathrm{x}$ for 'Divine Purpose'. On Morgan's writings in the emergentist tradition see David Blitz, Emergent Evolution: Qualitative Novelty and the Levels of Reality, Kluwer: Dordrecht, 1992, Chapters 6-9. 
Exactly how familiar Thorpe was in 1927 with these larger philosophical and theological dimensions to Morgan's work is unclear. But he certainly knew about Morgan, who, aside from his professional standing in the field that Thorpe was entering, was a local celebrity in Thorpe's home town of Hastings, right next to St Leonards-onSea. Morgan had moved to Hastings after retirement from the University of Bristol in 1919. Thorpe in The Origins and Rise of Ethology remembered Morgan as a 'striking figure about the place, the most impressive feature being his white beard, which in retrospect seems to have been a yard long!'7

MacBride too had been seen in action earlier, at an event that Thorpe later recalled as making the greatest impression on him of all of his undergraduate experiences. The occasion was a lecture presented in April 1923 to the Cambridge Natural History Society by the controversial Vienna zoologist Paul Kammerer on his experimental breeding research in support of the Lamarckian inheritance of acquired characters, using midwife toads and other animal species. Thorpe, then reading for an agriculture degree at Jesus College, was one among a large number of undergraduates present, in the company of J.B.S. Haldane and a number of Britain's most senior zoologists, including MacBride. By all accounts Kammerer, lecturing in English and exhibiting the few specimens that the war had spared, acquitted himself impressively. Even so, the debate afterwards was vigorous, with MacBride, a long-time advocate of Lamarckian inheritance in general and Kammerer's experimental evidence for it in particular, stepping forward as Kammerer's defender. MacBride continued in that role in the months and years that followed, even after, in the autumn of 1926, allegations of fraud against Kammerer, and his subsequent suicide. ${ }^{8}$ If the odour of scandal still lingered over Lamarckism when MacBride ascended the platform at St Leonard's-on-Sea, he drew no attention to it. At the start of his lecture, he noted that whereas his had once been a lone voice in favour of Lamarckian evolution and Kammerer's experiments, biological consensus had now swung behind him. According to MacBride, it was now plain that evolutionary change did not proceed by large-scale mutations à la the Mendelian-inchief William Bateson (Kammerer's nemesis), nor by the small-scale chance variations of Darwinian natural selection, but by heritable structural changes that came about in response to altered environments. When habitual activity was involved, the structural change was slow in coming but then permanent. Otherwise - and as in the cases he examined through most of his lecture, to do with domesticated goldfish - the change was rapid but temporary and easily reversed. ${ }^{9}$

7 Thorpe, op. cit. (3), p. 29. For Thorpe's biography see Gregory Radick, 'Thorpe, William Homan', in Noretta Koertge (ed.), New Dictionary of Scientific Biography, vol. 7, Detroit: Charles Scribner's Sons, 2008, pp. 42-45; and more extensively R.A. Hinde, 'William Homan Thorpe 1902-1986', Biographical Memoirs of Fellows of the Royal Society (1987) 33, pp. 620-629.

8 On Kammerer's lecture see Arthur Koestler, The Case of the Midwife Toad, London: Picador, 1971, Chapter 7; for Thorpe's testimonial see p. 70. On MacBride's Lamarckism see Peter J. Bowler, 'E.W. MacBride's Lamarckian eugenics and its implications for the social construction of scientific knowledge', Annals of Science (1984) 41, pp. 245-260, esp. 247-250.

9 E.W. MacBride, 'The nature and origins of mutations', Transactions of the South-Eastern Union of Scientific Societies (1927), pp. 13-21. 
The horizon-sweeping MacBride addressed his audience as president of the Zoological Section of the union. By unsurprising contrast, the neophyte Thorpe's paper, 'The fauna of brackish pools of the Sussex coast', was a narrowly focused affair. 'The object of the work', he announced, 'is to study the various forms of life, more especially the insects, in relation to the changes in the salinity of the medium; and it is hoped, eventually to obtain a fairly complete knowledge of the ecology of the locality'. Even so, what might in other hands have been a humbly empirical, data-for-data's-sake local survey, of little larger consequence, turned out to be a point of entry into the major theoretical problem of habitat extent - that is, of why animal habitats extend over the areas they do, and of what enables or prevents animals from extending their habitats even further. The particular habitat extension puzzle which brackish water swirled around, Thorpe explained, was the failure of freshwater insects to colonize marine water, though seemingly an obvious next move in their evolutionary expansion. What held them back? Was it to do with the sometimes greater salinity of boundary-marking brackish water compared with marine water - the brackish water thus functioning as the fluid equivalent of an impassable mountain or gorge? Thorpe's own investigations so far - including, he indicated, some experiments - suggested otherwise, as they showed that some insect species, and especially those belonging to more advanced, evolutionarily recent orders, tolerated brackish conditions remarkably well. The puzzle, Thorpe reported to MacBride and the rest of his audience, thus remained work in progress. ${ }^{10}$

Over the next ten years, Thorpe's interests in habitat and the responses of animals to its challenges brought him into ever closer contact with research into the evolutionary consequences of habit - and even, briefly, into friendly contact with the subject's most vocal Lamarckian exponent, MacBride. We turn next to consider Thorpe's path through the c.1930 debate over Lamarckism. His interventions and interactions are worth tracking in a little detail. For one thing, his professional milieu - British, elite, zoological, on the border between theoretical and applied sciences - was far more openminded about the possibility of habitually acquired characters being inherited than tends to be remembered now, when it is seen as the lost cause of Shavian romantics, proto-Lysenkoist botanists and other assorted outliers (MacBride). ${ }^{11}$ For another, although Thorpe's own support for the inheritance of acquired characters was shortlived and heavily hedged, he took away from this period a vivid sense of the easily overlooked role in evolutionary change of animal action, and ultimately of purposive animal

10 W.H. Thorpe, 'The fauna of brackish pools of the Sussex coast', Transactions of the South-Eastern Union of Scientific Societies (1927), pp. 27-34.

11 Cf. Marion J. Lamb, 'Attitudes to soft inheritance in Great Britain, 1930s-1970s', in Snait Gissis and Eva Jablonka (eds.), Transformations of Lamarckism: From Subtle Fluids to Molecular Biology, Cambridge, MA: MIT Press, 2011, pp. 109-120, esp. 110; Peter J. Bowler, The Eclipse of Darwinism: Anti-Darwinian Evolution Theories in the Decades around 1900, Baltimore: Johns Hopkins University Press, 1983, pp. 98106; and Richard W. Burkhardt Jr, 'Lamarckism in Britain and the United States', in Ernst Mayr and William B. Provine (eds.), The Evolutionary Synthesis: Perspectives on the Unification of Biology, Cambridge, MA: Harvard University Press, 1980, pp. 343-352. An excellent starting point for anyone wishing to explore the depth and breadth of scientific interest in Lamarckian inheritance c.1930 is the discussion in Richard Levins and Richard Lewontin, 'The problem of Lysenkoism', in Levins and Lewontin, The Dialectical Biologist, Cambridge, MA: Harvard University Press, 1985, pp. 163-196, 176-179. 
action. That the period was also a religiously intense one for him, as he began exploring the Quaker faith that he would formally adopt in the mid-1940s, makes a closer look all the more promising for insight into what followed.

\section{III}

After his public debut at St Leonards, Thorpe did well: studying in California on a Rockefeller Fellowship (1927-1929), getting his $\mathrm{PhD}$ in agricultural science from Cambridge (1929), and landing a job in the new parasite laboratory run by the Imperial Bureau of Entomology in the Buckinghamshire village of Farnham Royal. He now had a specialist area, biological control - an applied-science form of the habitat-extension question - and within that area he had an organism, the ermine moth, Hypomeuta padella, whose infestations occasionally brought fruit-tree orchards to ruin, but itself could suffer curtailing infestations from parasites. In a series of ever-more-commanding publications, Thorpe reported and reflected upon experiments showing that the two main moth variants - differing in colour and in habits but not in structure - amounted to distinct species-in-the-making or 'biological races', their differences maintained via their preferential mating with like variants as well as their preferential feeding on different host plants, apple trees or hawthorn trees. Placed in cages with diverse fruit-tree branches, moths from apple-preferring parents more often than not chose apple for egg laying, and moths from hawthorn-preferring parents more often than not chose hawthorn. These preferences, moreover, appeared to be instinctual, in that they were not easily modified - only starvation induced a larval moth to feed on the other sort of wood - and they manifested at egglaying time even in individuals that had not acquired the taste when young. ${ }^{12}$

What, if anything, did all of this mean for Lamarckism? In a 1929 paper, completed before he took up his new position, Thorpe was guarded, noting similarities between his studies and the recent, avowedly Lamarckian, experimental work of the Newcastle biologist J.W. Heslop Harrison on egg-laying preferences in sawflies, but then dismissing as 'entirely speculation' any thoughts about whether differential feeding patterns, kept up over umpteen generations, might be the cause of the differentiating biologies or whether the causation went the other way around. ${ }^{13}$ In a 1930 paper, however, he went further, both in embedding his own results within a comprehensive survey of recent work on biological races in insects and beyond, and in closing with a bravura summary of the achievements of the burgeoning experimental literature on Lamarckian inheritance. 'In conclusion, then', he wrote,

we may say that many of these experiments are easily explained on some form of Lamarckian theory, but extremely difficult to account for on any other lines. If the hypothesis were not such a debatable one the evidence might well be regarded as almost conclusive for, to quote

12 I am indebted in this section to the pioneering coverage of this period of Thorpe's career in Burkhardt, op. cit. (5), pp. 339-341.

13 W.H. Thorpe, 'Biological races in Hypomeuta padella L.', Journal of the Linnean Society of London, Zoology (1929) 36, pp. 621-634, 633; J.W. Heslop Harrison, 'Experiments on the egg-laying instincts of the sawfly, Potania salicis Christ., and their bearing on the inheritance of acquired characters; with some remarks on a new principle of evolution', Proceedings of the Royal Society B (1927) 101, pp. 115-126. 
Thompson and Parker (1928), 'it is probably the only intelligible theory of a natural evolutionary process ever advanced.' It seems equally certain, however, that none of the experiments recorded in these pages has been on a sufficiently extensive scale to carry complete conviction on the point. They do, however, suggest most profitable fields for further work of this nature and, taken together, they provide a quite considerable amount of the ever-growing body of circumstantial evidence for the theory. ${ }^{14}$

'Thompson' here was Thorpe's boss at Farnham Royal, William R. Thompson, an Ontario-born agricultural entomologist. In an obituary notice of Thompson, Thorpe recalled that biological races and Lamarckian inheritance were the topics of their most memorable work discussions. But they also met up often at the older man's home for marathon evening conversations on philosophy, in particular the neo-scholastic stance on science that Thompson had been developing for some years, and which would take public form in his book Science and Common Sense: An Aristotelian Excursion. Philosophically, Thompson disapproved of the role that Darwinian theory assigned to chance, on the view that the resulting theory was so alien from common-sense ways of understanding the world as to be unintelligible. Empirically, too, Thompson regarded the recent run of experimental studies of host preferences as sufficiently suggestive as to warrant a much wider and more rigorous programme of research into the inheritance of acquired characters. Even so, according to Thorpe, when Thompson saw the draft of the paper quoting him and his collaborator H.L. Parker to pro-Lamarckian effect, he was not encouraging, citing the professional difficulties that might hamper Thorpe's career as a result. Thorpe ignored the advice (which may well, one suspects, have been given in reverse-psychological spirit). ${ }^{15}$

While he also gave Thompson's form of Catholicism a wide berth, it was in just this period of philosophical-religious companionship that Thorpe, raised a Congregationalist, began attending Quaker meetings, at a Friends' Meeting House down the road from Farnham Royal. It would be as easy to read too much as too little into this conjunction. At the one extreme, there is no reason at all to think that incipient Lamarckism quickened Thorpe's interest in Quakerism or vice versa, much less to hunt up parallels and resonances that might explain how, for Thorpe at least, Quakerism and Lamarckism came to seem a singularly good fit for each other. But at the other extreme, it would be naive to suppose that someone as thoughtful as Thorpe would have seen no connections between his new scientific explorations and his new religious explorations. The vague assertion of one of his obituarists, in the Quaker journal The Friend, that it is not without significance that his total commitment to Friends [in 1945] and to the study of animal behaviour happened at the same time', seems about right. It is likewise not without significance that in 1930, when his earliest animal behaviour work led him to ally himself publicly with the community of Lamarckians and so to risk opprobrium for a modest form of scientific heresy, he made his first visits to a community of Christian

14 W.H. Thorpe, 'Biological races in insects and allied groups', Biological Reviews of the Cambridge Philosophical Society (1930) 5, pp. 177-212, 208, quoting from W.R. Thompson and H.L. Parker, 'Host selection in Pyrausta nubialis, Hübn.', Bulletin of Entomological Research (1928) 18, pp. 359-364, 360.

15 W.H. Thorpe, 'William Robin Thompson 1887-1972', Biographical Memoirs of Fellows of the Royal Society (1973) 19, pp. 654-678, esp. 661-662. Science and Common Sense was published in 1937. 
believers who, though belonging to the same Dissenting spectrum as his parents, stood well outside the tradition he was raised in. ${ }^{16}$

In March 1931, Thorpe, now his late twenties, gave a talk on his latest work to the Association of Economic Biologists in London, at Imperial College - MacBride's institution. He was there, and a few weeks later asked Thorpe a favour wrapped in a fan letter. MacBride explained that, having 'had the privilege of hearing you' deliver an address in which MacBride was 'deeply interested', he was writing to ask for references to some of the cases that Thorpe had mentioned - presumably cases of the sort discussed at the end of Thorpe's 1930 paper, reporting the successful production of new races and even species by the experimental inducing of inheritable changes of habit. 'I have undertaken to give a lecture in the Royal Institution on June 5 on "Habit the driving force in Evolution"', MacBride went on, 'and I shall like to show them some new slides'. To judge by a further letter from MacBride a little more than a week later, Thorpe's letter back was received with gratitude, prompting a further request from MacBride for information about illustrations relating to one of the cases that had featured in the Imperial address, involving the experimental transformation of head lice into body lice by the Quick Professor of Biology at Cambridge, George Nuttall. ${ }^{17}$

MacBride's Royal Institution lecture, subsequently published as a special supplement in Nature, marshalled Thorpe's work in support, along with Nuttall's and Heslop Harrison's. For MacBride, studies such as theirs, concentrating on the life histories of individual organisms, constituted one of three kinds of investigation throwing light on the process of evolution, along with locality studies dealing with different races in a single species and with different species in a single fossil lineage. All of the accumulated evidence so far, MacBride judged, was consistent with the view of 'Neo-Lamarckism' (his term) that change in environments causes organisms to adopt new habits, which in turn generate the inheritable structural changes that make for the gradual evolution recorded in the rocks. It was also becoming clearer how, at the cellular level, such habit-induced structural changes could become inheritable. At the same time, according to MacBride, evidence was mounting against the Darwinian view that the process goes the other way, with spontaneously changed structures accidentally producing the adaptive habits that fit fortunate individuals and their offspring more tightly to their changed environments. In making his negative case, he laid particular stress on the 'pure-line' experiments of Wilhelm Johannsen and others, as showing that normally arising variation is not inheritable, against the expectations of August Weismann and the other arch-Darwinians. 'The doctrine of the inheritance of acquired characters is by no means so dead as its opponents thought a generation ago', trumpeted the Nature

16 Anna M. Bidder, 'William Thorpe', The Friend, 16 May 1986, pp. 621-622, 621. Bidder says (at 621) that Thorpe applied for membership in the Friends in 1945, and Hinde, in his obituary, op. cit. (7), p. 630, that fifteen years before Thorpe had begun attending meetings while working at Farnham Royal.

17 Letters from E.W. MacBride to W.H. Thorpe, 21 April and 1 May 1931, in the Papers of W.H. Thorpe, Manuscripts Reading Room, Cambridge University Library, Add.8784, Box (aka 'Set') 6, 'M' sheaf. The lice experiments were reported in G.H.F. Nuttall, 'The systematic position, synonymy and iconography of Pediculus humanus and Phthirus pubis', Parasitology (1919) 11, pp. 329-346. 
editorial in the issue carrying the lecture. Although there was room for disagreement about whether all of the experiments that MacBride discussed bore the weight of his neo-Lamarckian interpretation, 'we view with sympathy his championship of the directive force of the organism in the evolutionary race'. ${ }^{18}$

But within professional biology, the tide was moving in the other direction. Between 1930 and 1932, R.A. Fisher, Sewall Wright and J.B.S. Haldane published work swiftly regarded as having put Darwinian natural selection theory on a newly secure, mathematically impressive, population-genetical foundation. Haldane spelled out the consequences for neo-Lamarckism unsparingly in a Royal Institution lecture in the spring of 1932. Framed as an answer to MacBride's 1931 lecture, and likewise published afterwards in Nature, Haldane's 'The hereditary transmission of acquired characters' made quick work of the experimental evidence that MacBride had exhibited. All of it, in Haldane's view, could be explained as due to the effects of unintentional selection, as when the transfer of larvae to an unaccustomed foodstuff functions to kill off all but the individuals with favourably disposing genetic variation. As for pure-line experiments, the conclusion to draw from them was not that Darwinian change in nature failed to happen, but that evolutionary change of whatever sort, Darwinian or Lamarckian, could not take place within a genetically uniform population. The challenge for the Lamarckian theorist, Haldane went on, was to identify a form of evolutionary change in a genetically mixed population which could not be explained as due to selection. Furthermore, in rising to that challenge, the Lamarckian would do well to disown the popular notion that there was something upliftingly vitalist about the inheritance of acquired characters and something depressingly mechanical about natural selection. Vitalism or mechanism can go just as easily with the one process as with the other, or with neither (Haldane's agnostic preference), according to intellectual taste. Those seeking for cosmic consolation from biological theory can, Haldane advised, surely find it more easily in the view that, up to now, evolution's slow, blood-soaked progress cannot be blamed on minds driving the process in that way on purpose. ${ }^{19}$

Neither Thorpe - who left Farnham Royal in 1932 for a lectureship at Cambridge nor anyone else with a stake in Lamarckism seems to have taken Haldane's advice. Be that as it may, within a few years Thorpe was firmly on Haldane's side of the question of the inheritance of acquired characters, though retaining, as a legacy from the Lamarckian excursions of the Farnham Royal days, an abiding interest in animal activity as an evolutionary cause in its own right. Both the shift and the survival are plain in a 1937 paper with a junior colleague at Cambridge, F.G.W. Jones, entitled 'Olfactory

18 E.W. MacBride, 'Habit: the driving force of evolution', Supplement to Nature (20 June 1931) 127, pp. 933-944, 942 on Thorpe; 940 on the differences between Lamarck's views and Neo-Lamarckism. Editorial quotations from the first item in the 'News and views' section, Nature, 20 June 1931, p. 946.

19 J.B.S. Haldane, 'The hereditary transmission of acquired characters', Nature, 4 and 11 June 1932, pp. 817-819, 856-858. For Fisher's critical remarks on Lamarckism around the same time see, for example, R.A. Fisher, 'Inheritance of acquired characters', Nature, 15 October 1932, p. 579; Fisher, 'Indeterminism and natural selection', Philosophy of Science (1934) 1, pp. 99-117, esp. 109-112; and Fisher, 'Adaptation and mutations', School Science Review (1934) 1, pp. 294-301, esp. 295-297 - all gathered in Collected Papers of R.A. Fisher, vol. 3 (ed. J.H. Bennett), Adelaide: University of Adelaide, 1973. 
conditioning in a parasitic insect and its relation to the problem of host selection'. The body of the paper reported a series of experiments making use of an olfactometer - basically a glass tube choice chamber for insects, which, by heading left or right at a junction point, express a preference for one smell over another - conducted in order to get more precise data on a phenomenon recently established by Thorpe: that in insect parasites which identify their usual host by smell, individuals reared on the larvae of an alternative host contaminated with the smell of the usual host will later on, as egg-laying adults, show on average a weakened preference for the usual host. In one trial, as per Lamarckian expectations, a greater proportion of individuals in the eighth generation preferred the alternative host than in the first generation. The difference, however, was not statistically significant, and in another trial the proportion expressing the acquired preference actually got smaller. 'It is quite clear', wrote Thorpe and Jones in summary, 'that the work so far gives no indication of any inheritance of acquired characters'. But that did not mean, they went on, that olfactory conditioning had no evolutionary significance. On the contrary, even a small amount of it could, under natural conditions, suffice to form an 'ecological barrier', isolating one sub-population from another. Once such a barrier exists, conditions are ripe for the emergence and preservation of genetic changes that might make the acquired preferences hereditary - a pseudoLamarckian process fitfully known to that point as 'organic selection' and later on as 'the Baldwin effect', but with several co-discoverers in the late 1890s, among them Conwy Lloyd Morgan. ${ }^{20}$

These themes became ever more pronounced in Thorpe's work during the war years, which he spent in England as a conscientious objector. ${ }^{21}$ Via Julian Huxley's enthusiastic coverage in his Evolution: The Modern Synthesis (1942), the Baldwin effect and Thorpe's empirical confirmations of it went on to become still more general themes, as I will consider more fully in the final section. But to stay with Thorpe himself for the moment, the war years saw him delve ever more deeply into the scientific literature on animal learning - a literature that counted as a near neighbour to the one he contributed to with his work on olfactory conditioning and host selection. ${ }^{22}$ It is time to consider in more detail his encounter with the sciences of animal mind and behaviour, especially those forms in dissent from a vision of the animal as a stimulus-response machine.

20 W.H. Thorpe and F.G.W. Jones, 'Olfactory conditioning in a parasitic insect and its relation to the problem of host selection', Proceedings of the Royal Society B (1937) 124, pp. 56-80, 78. On how J.M. Baldwin rather than Morgan or H.F. Osborn came to be remembered as the discoverer of organic selection see Robert J. Richards, Darwin and the Emergence of Evolutionary Theories of Mind and Behavior, Chicago: The University of Chicago Press, 1987, pp. 480-495.

21 See, for example, W.H. Thorpe, 'Ecology and the future of systematics', in Julian Huxley (ed.), The New Systematics, London: Oxford University Press, 1940, pp. 341-364; Thorpe, 'Animal learning and evolution', Nature (14 July 1945) 156, p. 46; Thorpe, 'The evolutionary significance of habitat selection', Journal of Animal Ecology (1945) 14, pp. 67-70.

22 In a footnote in his 1930 paper, Thorpe observed that while the term 'biological races' was better than 'physiological races' for capturing the sense of differences based in preferences rather than structures, he followed his boss Thompson in regarding 'psychological' as better still, especially for insects; Thorpe, op. cit. (14), p. 180. 
IV

The effects of that encounter on Thorpe's research ambitions became publicly visible in an extraordinary suite of six articles that he published in 1943 on animal learning - an impressive start to a project in self-education that culminated in 1956 in his professional masterpiece, Learning and Instinct in Animals. To appreciate the connections that he saw between his new interests in animal learning and his evolving evolutionary and religious commitments, however, we do better first to consider something earlier and unpublished: a long letter of September 1941 to the Cambridge-based Congregationalist minister and theologian John S. Whale, whose recent open lectures on Christian doctrine at the university had just been published. Thorpe wrote to congratulate Whale on the marvellous job he had done but also to raise a few queries.

One line of questioning concerned the light thrown by the theory of evolution on the nature of $\sin -$ a topic that Whale dealt with at length. But where Whale had rejected evolutionary theory as offering no explanation whatsoever for why man is sinful, Thorpe reckoned that the theory offered exactly the explanation that Christians seek, since it depicts man's mind as mostly not under his control. On an evolutionary understanding, wrote Thorpe,

by far the greater part of [human] mental structure appears to have been produced by and adapted to solving the problems involved in survival as an animal. Psychologically the Will ... has in every man all the time everywhere to contend with the great mass of inherited mental structure which morally speaking, is sheer dead weight.

The real theological puzzle, he went on, is not why we are sinful, but why we are so sinful, in that we might well have had a better-functioning moral sense. For a helpful statement of the problem, if not of the solution, Thorpe recommended Leonard Hobhouse: 'There is something in what Hobhouse says - "Perhaps the real difficulty is to imagine a mind which could make us living beings so well but not make us better." But this is part of the mystery central in the whole universe and its existence and development in time.'23

No thinker on animal agency mattered more for Thorpe than Hobhouse. Appointed to the first chair in sociology in Britain (at the London School of Economics), Hobhouse was, from 1907 until his death in 1929, a leading light of British liberalism. He assumed that role, however, as the most energetic and influential British successor to Herbert Spencer, with a career - and ultimately a collected works - that resembled an updating of Spencer's attempt systematically to recast the whole of human knowledge on evolutionary terms. For Hobhouse, evolution was a literally mind-expanding process that, with the arrival of humans, had become self-conscious and, potentially, self-directing, to morally and spiritually uplifting ends. Thorpe never lost an opportunity to stress the depth of his intellectual debt. In his Gifford Lectures, Animal Nature and Human

23 Letter from W.H. Thorpe to J.S. Whale, 22 September 1941, Thorpe Papers, Box 8, Bundle i, Folder 1; J.S. Whale, Christian Doctrine, Cambridge: Cambridge University Press, 1941. I have not identified the source of the quotation from Hobhouse (if indeed it is a quotation), but it is in keeping with the discussion in his Morals in Evolution, 2 vols., London: Chapman \& Hall, 1906, vol. 2, pp. 127-141. 
Nature, delivered in 1969-1971 and published in 1974, in a section entitled 'The refutation of reductionism', he testified, 'Amongst philosophers and logicians, particularly amongst those who have given special attention to scientific problems, many names could be mentioned, including that great thinker L.T. Hobhouse, whom I like to mention first because I owe so much to his writings. 24

Thorpe knew the wider oeuvre. But two door-stopper books on evolution became especially important. Mind in Evolution (1901; second edition 1915) commandingly set forth both a new theory of the multiple stages by which mind had grown in power over the course of animal evolution and the evidence in favour of that theory, including evidence from animal learning experiments that Hobhouse had conducted himself at Belle Vue zoological gardens in Manchester. A major target was the young American psychologist Edward Thorndike, whose recently published puzzle-box experiments in which he had placed hungry cats and monkeys in specially designed crates, timed the animals' efforts to open the doors and get the food just beyond, and interpreted the results in strict accord with Morgan's canon - appeared to show that intelligent activity by animals was always due to blind trial-and-error learning. Hobhouse responded with a different set of experiments where success could not come about gradually by trial and error but only because, more or less suddenly, the animal understood enough about its situation to act deliberately, on purpose. The iconic version of these experiments - chimps stacking boxes to get at a banana suspended overhead - was due to the later work of the German gestalt psychologist Wolfgang Köhler, who influentially introduced the word 'insight' to name the mental capacity called upon, of grasping the relations between the objects seen. But Köhler modelled his experiments and analysis closely on those of Hobhouse. And for Hobhouse, they served his larger argument on the progressive, upwards-by-degrees character of mental evolution, with each successive stage bringing not merely increase in the ability to frame and handle ideas but also concomitant growth in moral capacity and harmonious action. Under natural selection, progress had been slow. But now, with mind taking over as the driving force, producing ever improving understanding of the internal and external conditions on which its progress depends, the prospect of rapid further advance was achievable as never before. ${ }^{25}$

Mind in Evolution ended with some reflections on how the evolutionary process Hobhouse had described was neither mechanical nor teleological but something untidily in between. Spelling out that third option in more detail was the burden of Development and Purpose: An Essay towards a Philosophy of Evolution (1913; second edition 1927).

24 W.H. Thorpe, Animal Nature and Human Nature, London: Methuen, 1974, pp. 349, 45. See too, for example, Thorpe, Biology and the Nature of Man, London: Oxford University Press, 1963, pp. 54, 109; Thorpe, Biology, Psychology and Belief, Cambridge: Cambridge University Press, 1961, p. 44; and as discussed in the next section, Thorpe, op. cit. (2), pp. 8 (pamphlet), 13 (article). On Hobhouse see Gregory Radick, The Simian Tongue: The Long Debate about Animal Language, Chicago: The University of Chicago Press, 2007, pp. 211-214; and Chris Renwick, British Sociology's Lost Biological Roots: A History of Futures Past, London: Palgrave Macmillan, 2012, esp. pp. 98-120, 170-180.

25 L.T. Hobhouse, Mind in Evolution, London: Macmillan, 1901; Radick, op. cit. (24), pp. 214, $222-223$. Morgan later credited Hobhouse and successors such as Köhler with having shown that apes and to a lesser extent monkeys had reached a higher mental level of 'sub-rational' foreplanning. Morgan, Life, Mind and Spirit, op. cit. (5), pp. 211-212. 
Thorpe revered it, and rightly so. The aim was to show that two independent lines of investigation - the inductive study of the evolution of life and the deductive analysis of the operations of reason - converge on a picture of reality as a developing work-inprogress, characterized by an ever greater degree of harmony across parts which are ever more fully integrated into ever more comprehensive wholes. In Hobhouse's view, when we understand that harmony is the goal of life as much as it is the goal of reason, we understand not only why purely mechanical explanations, making no reference to purpose, never seem adequate, but also why our judgement of that inadequacy can be trusted as correct. So how, then, should we put together mechanism and teleology? A clear statement of the solution was, at this mid-point in the world process, with both reality and the human mind's grasp of it still under development, beyond human reach. But Hobhouse's best shot at a summing up was in a phrase that Thorpe came to cherish: 'conditioned purpose'. Purpose was as real as mechanical cause and effect but operated under the latter's constraints, under the conditions it imposed. The growth of mind over the evolutionary long run belonged to the still-longer-run story of the growth of purpose's mastery over conditioning mechanism. There was even, for Hobhouse, a new understanding here of God, as 'that of which the highest known embodiment is the distinctive spirit of Humanity', itself understood 'as the spirit of harmony and expanding life, shaping the best actions of the best men and women'. ${ }^{26}$

Hobhouse the holistic thinker on animal mind made an appearance further on in Thorpe's 1941 letter to Whale, in a remarkable paragraph worth quoting in full. It shows, first of all, how fully Thorpe already identified with biologists and psychologists in a broadly Hobhousian mould, insistent that animals are not at all the stimulusresponse machines presumed in the work of the American behaviourists who followed on from Thorndike. Among the virtuous for Thorpe, alongside Hobhouse, were Henry Eliot Howard and E.S. Russell in Britain, the Lamarckian William McDougall in the USA (a transplanted Brit), the German gestalt psychologists, the Dutch zoologist J.A. Bierens de Haan, and the Austrian zoologist Konrad Lorenz, whose work with another Dutchman, Niko Tinbergen, to define a new, bird-focused biological science of animal instinct and instinct-conditioned learning - ethology - would give a new direction to Thorpe's research career in the postwar years. (Thorpe referred to the above under the banner of a now unfamiliar term, 'hormic psychology', popular in the 1920s. Roughly speaking, if you wanted to interpret animal behaviour as the upshot not of mechanism but of mind, then hormism - from the Greek for 'impulse', horme was for you. ${ }^{27}$ But the paragraph is also revealing of how readily Thorpe connected the dots between the richer notion of animal mental life that these admired men defended and the need to recognize the capacity of animals for pain and suffering - something that, much later, he would take pioneering political action to alleviate:

26 L.T. Hobhouse, Development and Purpose: An Essay towards a Philosophy of Evolution, London: Macmillan, 1913, pp. xxvi, 371.

27 On hormism see Morgan, Life, Mind and Spirit, op. cit. (5), pp. 87-93; also J.C. Flugel, A Hundred Years of Psychology 1833-1933, London: Duckworth, 1933, pp. 270-278. As Flugel stressed, hormic psychology was identified most closely with McDougall, who was increasingly well known for Lamarckism-affirming learning experiments with rats (see ibid., p. 278). 
One more matter connected with Comparative Psychology ... You probably know that the tendency is to assign a bigger and bigger role to conation and purpose in animal behaviour. There seems no getting away from the 'hormic psychology' of Bierens de Haan, Russell, McDougall, Hobhouse etc. These and the Gestalt psychologists seem to have brought about not merely the decay but the final dissolution of 'Behaviourism'. Now obviously one must be extremely cautious about attributing mental states to animals; behaviourism was itself a natural reaction from a crude anthropomorphic view. Obviously we can never know the animal mind directly. But we have reached the stage now when it seems utterly perverse to deny some kind of consciousness, emotion and purpose at least to the higher vertebrate animals. As the work of Eliot Howard, Lorenz and many others seem[s] to show, much of bird behaviour is utterly meaningless without supposing certain emotions very similar to ours and some sort of consciousness seems indubitable in the higher mammals at least. (Although 'consciousness' is a term which some animal psychologists equate with 'experience'; to my mind unjustifiably.) If then the present day comparative psychologists are right I think it follows that there must be in Nature a great amount of pain and suffering, some of it apparently meaningless. This suffering will of course be very different to and very much less than human suffering in that apprehension is probably almost if not entirely lacking. But still it seems as if it must be there to some extent, even if only momentarily. I take it that it is the essence of true religion that it ultimately makes sense of the human suffering in the world; if it does not do so it fails finally. Religion can make sense of human suffering because man is a moral being and has something divine in his nature. But what of the animals? Are they too capable of salvation? And what of human and sub-human suffering prior to the coming of revealed religion? Are we to regard the travail of the whole creation justified because it was able at last to give rise to man? This seems to present such a terrifying picture of God that the mind instinctively recoils from it. The 'natural world' seems after all a mixture of good and evil as does the 'human world' but lacking any hope of salvation. As long as one could regard animals as exquisitely beautiful automata, all was well. As I say we can never be sure in the sense of having strict proof, but the old view does seem less and less tenable. ${ }^{28}$

Two years later, in 1943, Thorpe published those six animal-learning articles. Three of them were successive parts of a single survey, 'Types of learning in insects and other arthropods', which included discussion of insight learning, noting Hobhouse's role in its study. The tone is strikingly sympathetic, with Thorpe at one point suggesting that 'an enormous amount of so-called trial and error learning of the higher vertebrates does in fact involve insight at some stage'. ${ }^{29}$ Another of his papers that year reported his own first observation of learning in a higher vertebrate: a great tit who had landed on the bird table in his garden in Cambridge. In a sort of upside-down version of the box-stacking experiment with chimps, the bird in Thorpe's set-up - not, it seems, deliberately contrived, but just an ordinary feature of the table - had to pull up a thread in stages, holding the pulled-in loop in its foot, in order to get at a cheese rind suspended at the bottom. 'I was greatly impressed by the smooth ease and certainty, and the entire absence of fumbling, with which the complete act was accomplished in a matter of a few seconds', wrote Thorpe. The act thus bore, he went on, all the hallmarks of

28 Letter from W.H. Thorpe to J.S. Whale, 22 September 1941, Thorpe Papers, Box 8, Bundle i, Folder 1, emphases in original. On Thorpe's animal welfare work see David A.H. Wilson, 'Animal psychology and ethology in Britain and the emergence of professional concern for the concept of ethical cost', Studies in History and Philosophy of Biological and Biomedical Sciences (2002) 33, 235-261, esp. 249-251, 256.

29 W.H. Thorpe, 'Types of learning in insects and other arthropods' (I), British Journal of Psychology (1943) 33, pp. 220-235, esp. 222-224, 224; Thorpe, 'Types of learning in insects and other arthropods' (II-III), British Journal of Psychology (1944) 34, 20-31, 66-76. 
insight learning: 'a real solution of a problem, distinguishing means and ends, based on apprehension of the essential relations in a situation and not upon the slow method of "Trial and Error"”.30

\section{V}

Twice over, the end of the Second World War marked a 'before' and 'after' for Thorpe. Before, he was an economic entomologist, specializing in crop pests and their parasites. After, he was an ethologist, specializing in birds and the experimental study of the interplay of instinct and learning in song acquisition. Before, he was a Congregationalist strongly attracted to Quakerism. After, he was a formal member of the Society of Friends. As we have seen, animal learning, and especially that part of it concerned with animals as purposefully acting agents, not mere machines, served to bridge not only the two parts of his scientific career but also his professional, scientific self and his personal, Christian self. The latter interconnections, however, remained a private matter, for discussions and correspondence, until the end of 1950, when Thorpe delivered his lecture on 'Evolution and Christian belief', from which I quoted near the start (on the animal under natural selection as 'a non-deterministic agent acting through the whole ecological complex of life and its environment').

The occasion was an invitation to address a conference in London on evolution and education, organized by groups headed up by the British Social Biology Council. But the more important releaser, as the ethologists used to say, was the Eddington Lecture earlier that year by his Cambridge colleague Ronald Fisher, 'Creative aspects of natural law'. Fisher took aim at the oft-repeated allegation that organic evolution as understood by neo-Darwinians like him was an uncreative and dispiriting process. Fisher diagnosed two mistakes at work here. One was the failure to appreciate that, according to the best recent physical science, all natural causation is indeterministic and so, to that extent, creative. Any causal system might well have been different from what it is. The other mistake - and, Fisher reckoned, it was the emotionally and morally resonant one - was to suppose that there must be something more to evolutionary creativity than what natural selection alone can accomplish, and/or that natural selection requires supplementing by a Bergsonian élan vital, a Lamarckian willing, a dash of Smutsian holism, or some other kind of magic extra if it is to be creative. But the magical extras do not exist, Fisher insisted, and even if they did exist, they would not explain the facts about evolution as we know them. By contrast, not only does natural selection, acting on natural genetic variation, explain what needs explaining, but also its means and ends, when viewed in the right way, fully satisfy cravings for evolution to be upliftingly creative. Under natural selection, and in parallel with some Christian teachings, it is the success or failure of the organism's enterprise, its commerce with the world, which counts. And that success or failure in turn can contribute

30 W.H. Thorpe, 'A type of insight learning in birds', British Birds (1943) 37, pp. 29-31, 29; with a followup paper the next year: Thorpe, 'Further notes on a type of insight learning in birds', British Birds (1944) 38, pp. $46-49$. 
creatively to the bringing about of new species, as when the extinction of the dinosaurs opened up new possibilities for mammals. ('Who knows', wondered Fisher, 'if the mammals would ever have evolved, but for the creative activity of the dinosaurs!') Indeed, at a time of growing awareness of human responsibility for extinction, there was scope too, Fisher urged, for creative new efforts by humans to preserve old species, and more generally to protect our fellow creatures from harm. ${ }^{31}$

Thorpe in his lecture warmly endorsed this vision of creative, Christian Darwinism. But his route to and from that destination was distinctively that of a Hobhousereading, ex-Lamarckian behavioural zoologist. After some opening reflections on affinities between Christianity and science in general, biology in particular, and the idea of an evolutionary family tree especially, he turned to Christian suspicions about natural selection, notably that it was wasteful, cruel, blind and amoral. The first two charges he dispatched easily enough. Natural selection looks wasteful only on the unacceptably anthropocentric view that humans are what the whole process is for, and cruel only on an outmoded understanding of natural selection as rewarding success in mortal combat rather than differential reproduction, coupled with an exaggerated estimate of animals' abilities to anticipate and dread the far future. But the alleged blindness of natural selection he found more problematic. Yes, loose talk about the 'randomness' of variations introduced confusions that were easily dissolved. Another source of confusion, however, was a deeply rooted but increasingly untenable conception of the organism as a mindless machine. 'I see no escape', wrote Thorpe,

from the view of living animals as psycho-physical systems. This is the conclusion reached by that undeservedly neglected philosopher, L.T. Hobhouse, who in his great work, Development and Purpose, defines purposive behaviour as 'the conditioning of the action of each part of a system by the causal tendency of the configuration as a whole', and sees this as the characteristic mode of reaction of the psycho-physical system. From this anticipation of the gestalt-psychologist's position he arrives, long before Smuts, at an essentially holistic philosophy of a conditioned purpose at the core of the world process.

In Hobhousian spirit, Thorpe was adept at making connections in an ever developing intellectual universe. Here he noted how well this conception of the organism chimed with the writings of the process philosopher Alfred North Whitehead and the systems theorist Ludwig von Bertalannfy. And once one saw the organism in this new, dynamic, driven, mind-over-matter way, then, Thorpe continued, not only did evolution under natural selection appear less blind, but also its explanatory power increased massively, as one could now much more plausibly, via the Baldwin effect, use it to explain the evolution of complex instinctive behaviour patterns. Only at this point did Thorpe come onto Fisher's perspective on creative evolution, as offering still more motivation for

31 R.A. Fisher, Creative Aspects of Natural Law, Fourth Annual Arthur Stanley Eddington Memorial Lecture, Cambridge: Cambridge University Press, p. 19. On the place of this lecture within Fisher's oeuvre see M.J.S. Hodge, 'Biology and philosophy (including ideology): a study of Fisher and Wright', in Hodge, Before and after Darwin: Origins, Species, Cosmogonies, and Ontologies, Aldershot: Ashgate, 2008, XIII, esp. pp. 256-262. From the beginning of the Eddington lecture series in 1946 through to 1975, Thorpe was chairman of the trustees; see Hinde, op. cit. (7), p. 631. 
dropping the blindness charge against natural selection. And in summarizing that perspective, Thorpe gave it a Hobhousian gloss:

we may say that the natural selection process is creative in the full meaning of the word, and that evolution involves a non-deterministic agent acting through the whole ecological complex of life and its environment. This, moreover, implies to my mind that if we can discern a purpose in the agent, there must also be a Purposer.

He brought the lecture to a close by observing, apropos of amorality, that only those who saw evolution as 'purposeless mechanism' (in Julian Huxley's phrase) up to the emergence of moral humans have puzzles to contend with here. ${ }^{32}$

A couple of letters that Thorpe received on the text of the lecture, published the next year, show that, at least for a couple of contemporaries, he did not succeed entirely in reconciling his bullishness on neo-Darwinian natural selection theory with what otherwise seemed his critical estimate of the limitations of that theory. In January 1951 he received a letter from a Cambridge colleague, the naturalist, theologian and historian of natural history Charles Raven. Raven congratulated Thorpe on a very lucid and helpful presentation of the virtues of the latest version of Darwinian theory, declared by Thorpe to be, as Raven quoted, 'the only adequate mechanism of evolution known'. Raven went on,

But having done so you then (as it seems to me) completely change the concept of organism. You introduce an idea of creativity, holism, purpose so that 'random' ceases to mean merely haphazard ... and a concept of the organism quite different from what has dominated biology [-] a concept clearly incompatible with the orthodox mechanistic view or (as I think) with the use of random - for random can only mean non-teleological whereas you speak ... of 'conditioned purpose.' I expect the position can be easily cleared up but I am bound to say to you what I said to Fisher that this new concept of the organism needs further explication. If there is creativity in the organism, then Natural Selection falls into its place as a sifting process. But this is not what it is claimed to be by Huxley or Darwin. ${ }^{33}$

Later that year, a Quaker theologian, Herbert G. Wood, sent a letter identifying a related but different problem. On the one hand, wrote Wood, Thorpe insisted that - to quote the paper - 'adaptive and orthogenetic trends cannot be explained in terms of any inward drive of the organism or race'. But a little way on, Thorpe claimed that 'the "drive" of such an animal is as much a part of it as its structure'. 'This looks to me as inconsistent', wrote Wood, 'but is the point you are making this - that a drive must be assumed or recognised, but does not explain as much as [Henri] Bergson \& others claimed for it?'34

There is a sense in which Thorpe spent the rest of his writing life attempting to resolve the difficulties touched on in these two letters. A major and indeed controversial part of

32 Thorpe, op. cit. (2), pp. 8-9, 11 (pamphlet), 13-14, 16 (article); T.H. Huxley and Julian Huxley, Evolution and Ethics, 1893-1943, London: Pilot Press, 1947.

33 Letter from Charles Raven to W.H. Thorpe, 12 January 1951, Thorpe Papers, Box 8, Bundle i, Folder 1, emphasis in original, quoting (inexactly) from Thorpe, op. cit. (2), pp. 5 (pamphlet), 10 (article).

34 Letter from Herbert G. Wood to W.H. Thorpe, 6 November 1951, Thorpe Papers, Box 6, 'W' sheaf, quoting from Thorpe, op. cit. (2), pp. 4, 9 (pamphlet), 9, 14 (article). Even if Thorpe's lecture failed to satisfy all comers, it did him no harm professionally, at least to judge by his election in 1951 to the Fellowship of the Royal Society. 
Learning and Instinct in Animals was devoted to expounding a biologically up-to-date theory of animal drive. (The discussion of insight learning stretched across three chapters. $)^{35}$ And he remained ready to applaud and apply new scientific work tending to show up Darwinian natural selection as less powerful than its propagandists said. The neo-Lamarckian twist on the peppered moth example which I quoted at the outset, from Science, Man and Morals, was not original to Thorpe but one he picked up from the evolutionary-developmental biologist C.H. Waddington's The Nature of Life (1961). ${ }^{36}$ The chemist-turned-philosopher Michael Polanyi's enthusiasm for emergence in the same period quickened Thorpe's interests in that alternative to gradualist Darwinism, long familiar from the pages of Hobhouse and Morgan. ${ }^{37}$ Around the time that Science, Man and Morals came out, Thorpe in a Nature review hymned the praises of a 1965 book, Internal Factors in Evolution by Lancelot Law Whyte. In epitomizing Whyte's case for how internal factors constrain natural selection, Thorpe echoed Raven's language (and Waddington's title): 'The nature of life limits its variation and is one factor directing phylogeny. Thus the mutations of which the consequences reach the Darwinian test have already been sifted by an internal selection process.'38

\section{VI}

As Fisher demonstrated, one could be a holistically inclined Christian Darwinian in midcentury Britain and not be bothered in the slightest about animal agency and its scientific neglect, or even about supposed tensions between mechanism and teleology. As we have seen, those concerns became Thorpe's thanks to scientifically formative contacts, not at all shared by Fisher, with Lamarckian evolutionary biology and Hobhousian insight psychology. Through the former, Thorpe learned that the formation of new habits could be evolutionarily consequential; through the latter, that the minds behind those habits could be treated as purposeful, and the results integrated into a broader picture of - to quote the title of one of his final books - purpose in a world of chance. In reconstructing these features of Thorpe's intellectual biography, I have drawn on some previously unexamined archived correspondence, without which their significance can be

35 W.H. Thorpe, Learning and Instinct in Animals, London: Methuen, 1956.

36 C.H. Waddington, The Nature of Life, London: George Allen \& Unwin, 1961, p. 90. Thorpe took extensive notes (preserved in the archive: Thorpe Papers, Box 8, Bundle ii, Folder 1) on Waddington's book and cited it in Science, Man and Morals. On Waddington's studies in the 1940s and 1950s of what he called 'genetic assimilation', but widely interpreted ever since as a variant of the Baldwin effect, see Brian K. Hall, 'Baldwin and beyond: organic selection and genetic assimilation', in Bruce H. Weber and David J. Depew, Evolution and Learning: The Baldwin Effect Reconsidered, Cambridge, MA: MIT Press, 2003, Chapter 8.

37 Michael Polanyi, Personal Knowledge: Towards a Post-critical Philosophy, Chicago: The University of Chicago Press, 1962 (first published 1958), pp. 382-404; Thorpe, op. cit. (1), pp. 20 ff. Documents preserved in the archive show that Thorpe and Polanyi spoke in the same session at the 1959 annual conference of the British Society for the Philosophy of Science and corresponded in the summer of 1962 about emergence in biology; Thorpe Papers, Box 8, Bundle ii, Folder 1. On Thorpe on emergence see Neal C. Gillespie, 'The interface of natural theology and science in the ethology of W.H. Thorpe', Journal of the History of Biology (1990) 23, pp. 1-38, 8-10.

38 W.H. Thorpe, 'Molecules and evolution', Nature (1966) 210, pp. 663-664, 664. 
hard to spot. Thus a long and in other respects deeply researched 1990 article on the links between Thorpe's religious thought and scientific work by Neal Gillespie - until now the only study of the subject - mentions Lamarckism and insight learning only in passing, misses out Hobhouse entirely, and concludes that '[i]t was the requirements of his natural theology more than the practical needs of his science that led Thorpe away from mechanistic reductionism (as he characterized it) and toward holistic biology'. 39

Just as a closer tracking of Thorpe's interactions with Lamarckism and, to give it a name, Hobhousism illuminates his particular case, the reverse is also true. Again, the pairing with Fisher is illuminating. Fisher had scientific dislikes, even hatreds. But The Genetical Theory of Natural Selection is not a work of dissent from some needing-tobe-overturned orthodoxy. It strengthened incipient orthodoxies across three mainstream sciences - Darwinian evolutionary biology, Mendelian genetics and Galtonian eugenics - by binding them together. (Reports of the 'eclipse of Darwinism' in the decades around 1900 are increasingly recognized as much exaggerated.) The further, easy fit with a rather conventional Anglican faith only underscores the extent to which Fisher's achievement was, through and through, establishment science. ${ }^{40}$ By contrast, when Thorpe took them up as his causes, the inheritance of acquired characters and the purposeful activity of animal minds had around them an ambience of daring and subversion. Relatedly, what he thus took up was defined mainly negatively, in terms of what was being rejected. These were protests against dismissiveness towards animal agency, on the part of postWeismannian Darwinians and post-Thorndikian behaviourists. Over the decades, he remained true to that dual rejection while ceaselessly experimenting with the intellectual resources best suited to articulating it (which, for the historian of science, makes his oeuvre a remarkably full record of anti-reductionist science and philosophy in the twentieth century). ${ }^{41}$ 'Nonconformism' - a standard label for the dissenting traditions within Protestant English Christianity - works too for the modestly heretical scientific positions that attracted the Congregationalist-turned-Quaker.

How far might such reflections on the category of 'protest science' be extended? One could, if one wanted, describe all sciences as protests, against ignorance if not against outright falsehoods, as well as, sometimes, against the authority fraudulently founded on them. There is a serious sense in which Copernicus protested against Ptolemaic orthodoxy, Newton Cartesian orthodoxy, Darwin the orthodox theory of independent special creation, Watson the introspectionist orthodoxy ... But there is an equally serious sense in which, for the sciences which count these men as begetters, the oppositional beginnings came to be transcended, to the point where it is now a job of work for historians to recall those otherwise invisible beginnings. Proponents of the Modern Synthesis version of natural-selection theory can give an account of what they believe without

39 Gillespie, op. cit. (37), 35.

40 See, in addition to Hodge, op. cit. (31), James R. Moore, 'R.A. Fisher: a faith fit for eugenics', Studies in History and Philosophy of Biological and Biomedical Sciences (2007) 38, pp. 110-135.

41 'Protest' was a category invoked at the time, for example by Morgan in Emergent Evolution, op. cit. (6), pp. 7-8: 'the whole doctrine of emergence is a continued protest against mechanical interpretation, and the very antithesis to one that is mechanistic'. 
having to criticize what they do not believe, much less rehearse the history of the debate from which their science emerged. A protest science, we might say, never has that luxury, or at least not yet. Its form is seemingly fixed in oppositional mode, its content - for that very reason (since what is rejected is more important than what is embraced) - permanently fluid, both in being hard to get hold of and in being prone to flow onward, sometimes in multiple directions at once. Lamarckism since the late nineteenth century has been a protest science par excellence. The science of animal agency, with Lamarckism as one of its sources, has been, and remains, another. Thorpe's peppered moths are thus exemplary not just of the phenomena that fall within this science's purview but also, as neo-Darwinian icons treated with sacrilegious glee, of the definitional dependency that is the calling card of protest science. ${ }^{42}$

Thorpe in protest mode made a lively impression on his contemporaries. In the late 1970s, Arthur Koestler, author of the era's bestselling historical and philosophical tracts against mechanical, reductionist science, hailed Thorpe as the spokesman for the 'hundreds of biologists' over the previous quarter-century who had come to reject neo-Darwinism and the dogmatic purposelessness it insisted upon. ${ }^{43}$ Over the quartercentury that followed, the reputation of the Modern Synthesis for standing in the way of a better, agency-friendly evolutionary biology only grew. ${ }^{44}$ But so, curiously enough, did awareness of a theoretical option that the Modern Synthesis had made available to its opponents on that front. The 'Baldwin effect' was so named by the great palaeontological synthesist G.G. Simpson, in a 1953 review essay surveying a decade of work that had accumulated after Huxley's discussion in Evolution: The Modern Synthesis. As Simpson showed, the possibility of heritable but non-Lamarckian fixation of learned, adaptive behaviours had received little attention from the time of its 1890s inaugural moment until Huxley wrote. Huxley regarded the principle as 'an important one which would appear to have been unduly neglected'. Simpson, by contrast, judged it a not-very-important variant form of natural selection - and certainly nothing unsettling for the Synthetic theory. ${ }^{45}$ Although Simpson's deflationist view prevailed into the 1980s, the Baldwin effect since that time has become an increasingly standard option

42 I first considered Lamarckism along these lines in a review essay, Gregory Radick, 'Deviance, Darwinian style', Metascience (2005) 14, pp. 453-457.

43 Arthur Koestler, Janus: A Summing Up, London: Hutchinson, 1978, quotation from Thorpe on p. 165. On Koestler's admiring relations with the anti-reductionist scientists of the era - many of them gathered in 1968 in Alpbach for the famous Beyond Reductionism symposium, which Thorpe chaired (the quotation is from his opening remarks) - see James F. Stark, 'Anti-reductionism at the confluence of philosophy and science: Arthur Koestler and the biological periphery', Notes and Records of the Royal Society (2016) 70, pp. 269-286.

44 See, for example, Richard C. Lewontin, 'Gene, organism, and environment', in D.S. Bendall (ed.), Evolution from Molecules to Men, Cambridge: Cambridge University Press, 1985, pp. 273-285; and more expansively Lewontin, The Triple Helix: Gene, Organism, and Environment, Cambridge, MA: Harvard University Press, 2000. Niche constructionism and developmental systems theory belong to the same family of criticism. Recent indictments of the Modern Synthesis in this tradition include Peter A. Corning, 'Evolution "on purpose": how behaviour has shaped the evolutionary process', Biological Journal of the Linnean Society (2014) 112, pp. 242-260 and D.M. Walsh, Organisms, Agency, and Evolution, Cambridge: Cambridge University Press, 2015.

45 G.G. Simpson, 'The Baldwin effect', Evolution (1953) 7, pp. 110-117; Julian Huxley, Evolution: The Modern Synthesis, London: Allen \& Unwin, 1942, p. 524. 
for anyone wishing to theorize beyond the limits of Fisherian, population-genetical Darwinism. ${ }^{46}$

What prompted Huxley to give the Baldwin effect such consequential prominence? The short answer is: Thorpe. ${ }^{47}$ Around 1936-1937, when Huxley began to gather material for the book that would give the Modern Synthesis its name, Thorpe's research on biological races entered its decisively post-Lamarckian phase. Huxley asked Thorpe for a chapter on the topic for a 1940 collection on the new systematics. ${ }^{48}$ In Evolution: The Modern Synthesis, in a chapter on speciation, Huxley - the most behaviourally attuned of the Synthesists - devoted a lengthy section to 'biological differentiation', concentrating more or less exclusively on work either done or discussed by Thorpe. It was here that Huxley provided his main exposition of what he called, interchangeably, 'organic selection' and 'the Baldwin and Lloyd Morgan principle'. ${ }^{49}$ Thorpe - who appears not to have known any of those names before - found Huxley's discussion clarifying, and made generous reference to it in a 1945 paper on animal learning and evolution that went further still in bringing the principle to the attention of neo-Darwinians such as Simpson. ${ }^{50}$ If Thorpe came to feel uncomfortable with the place that animal agency ultimately occupied in the Modern Synthesis, it was not for want of trying, and even, in a small but seemingly permanent way, succeeding. Anyone concerned not to treat the Modern Synthesis as a monolith could do worse than remember Thorpe's example. ${ }^{51}$

46 On the Baldwin effect's scientific trajectory see the papers gathered in Weber and Depew, op. cit. (36); and also a review essay on the volume by Kim Sterelny, 'Baldwin effects', Evolution and Development (2004) 6, pp. 295-300.

47 On Thorpe and the Baldwin effect see the brief but excellent discussion in Gillespie, op. cit. (37), pp. 3031. Oddly, the otherwise comprehensive Weber and Depew volume, op. cit. (36), includes just one minor and misleading mention of Thorpe (p. 143).

48 Huxley recounted the origins of what became Evolution: The Modern Synthesis in Huxley, op. cit. (45), p. 7. Correspondence from March 1938 preserved in the Julian Huxley archive at Rice University, Texas, shows that Thorpe was already at work then on the chapter for Huxley's New Systematics volume, published as Thorpe, 'Ecology', op. cit. (21). Many thanks to Emily Herring for sharing copies of these letters with me.

49 Huxley, op. cit. (45), pp. 295-308, 296.

50 Thorpe, 'Animal learning', op. cit. (21); Thorpe, 'Evolutionary significance', op. cit. (21) (the former is a precis of the latter). For Thorpe's sense of the paper's importance, in explaining how 'recent developments in genetics and in the study of animal learning make the Baldwin concept at once more probable and easier to understand', see Thorpe, op. cit. (35), pp. 256-258, 257. Simpson, distinguishing an animal's selecting of its environment from the Baldwin effect strictu sensu, cited Thorpe's paper as linking the two by showing how '[s]election of the environment may ... be a first step in the Baldwin effect.' Simpson, op. cit. (45), p. 111.

51 The pluralism of the Modern Synthesis has been a general theme in the historiography of recent decades, beautifully encapsulated in David Depew and Bruce Weber's line about the Synthesis being 'more like a treaty than a theory'. David Depew and Bruce Weber, Darwinism Evolving: Systems Dynamics and the Genealogy of Natural Selection, Cambridge, MA: MIT Press, 1995, p. 300. On behaviour's lack of full integration into the Synthesis, the prize one-liner is considerably older. In a 1957 review of Thorpe's Learning and Instinct in Animals, the Glasgow zoologist S.A. Barnett wrote, 'It was once said of certain investigations of population dynamics that the animals concerned did not behave at all: they merely numbered off from the right.' S.A. Barnett, 'The new ethology', New Biology (1957) 24, pp. 118-124, 118, emphasis in original. 